\title{
NOTES AND DESCRIPTION AMENDMENT OF TELIPOGON PHUYUPATAMARCENSIS (ORCHIDACEAE)
}

\author{
Benjamin Collantes ${ }^{1} \&$ Carlos Martel $^{2,3}$ \\ ${ }^{1}$ Inkaterra-Inka Terra Association, Andalucía 174, Lima 18, Peru \\ ${ }^{2}$ Institute of Evolutionary Ecology and Conservation Genomics, University of Ulm, Helmholtzstraße \\ 10-1 Containerstadt, D-89081 Ulm, Germany \\ ${ }^{3}$ Corresponding author: carlos.martel-gora@uni-ulm.de
}

\begin{abstract}
Telipogon phuyupatamarcensis is a Peruvian endemic and poorly known species. Living specimens of various populations were examined. An updated description, illustrations, figures and taxonomic notes are provided.
\end{abstract}

Resumen. Telipogon phuyupatamarcensis es una especie poco conocida y endémica de Perú. Especímenes vivos de diversas poblaciones fueron revisadas. Se proveen una descripción actualizada, ilustraciones, figuras y notas taxonómicas.

Key words: Andes, Cusco, Oncidiinae, Peru, type collection

Telipogon Kunth is a highly diverse orchid genus comprising around 200 accepted species (Dodson, 2003; Pridgeon et al., 2009; Martel \& Nauray, 2013). The genus taxonomy is quite problematic; this is a result of incomplete species descriptions and a limited number of specimens available, thus causing many species to be poorly known. In Peru, Telipogon is currently represented by 54 species growing in the cloud forest of the Andes (Collantes \& Martel, 2015); however, a few more are in process of description (Martel, in prep). Several of them present restricted distribution, are endemic to the country and may even occur in a single valley (Roque \& León, 2006; Nauray \& Galán, 2008). Telipogon phuyupatamarcensis W. Galiano, P. Nuñez \& A. Tupayachi is a Peruvian endemic species known to occur in a few localities of Cusco (Southern Peru; Galiano et al., 2003). The species was first misidentified as Telipogon venustus Schltr. (Christenson, 2003; Nauray \& Christenson, 2003); but it was soon after proposed as a new species by Galiano et al. (2003) and named after the type locality, Phuyupatamarca. The species has been widely accepted by Peruvian plant checklists and taxonomic works (Ulloa Ulloa et al., 2004; Roque \& León, 2006; Nauray \& Galán, 2008; Martel, 2014). However, some currently data compilers and online plant checklists do not list T. phuyupatamarcensis (e.g.
GBIF, IPNI, Kew Plant World checklist) or consider it with an unresolved name (e.g. The Plant List), but only Tropicos records it with a legitimate name.

After a careful analysis of living individuals of $T$. phuyupatamarcensis we found out that the description and line drawing provided by Galiano et al. (2003) are not accurate: the diagnosis and some morphological characters recorded by them (e.g. seated leaves, obovate labellum, perianth measures, among others) do not correspond with those of the actual T. phuyupatamarcensis or some were omitted in the description (e.g. callus shape and size). Therefore, an emended description is required for this taxon. To do so, two localities within the Machu Picchu Historical Sanctuary were visited, Phuyupatamarca and Chakicocha, to review specimens and to collect material for herbarium. We present here an emended description of $T$. phuyupatamarcensis. Illustrations, figures and ecological notes are also provided.

Telipogon phuyupatamarcensis W. Galiano, P. Nuñez \& A. Tupayachi. Cantua 11: 11. 2003 (FIG. 1-2)

TYPE: Peru. Cusco: Urubamba, Machu Picchu, Microcuenca, Camino Inka, Tunel Chaquicocha, 18 L 768442E 8537799N, 3650 m, A. Tupayachi, W. Galiano, R. Tupayachi, E. Suclli, M. Moreno, D. 


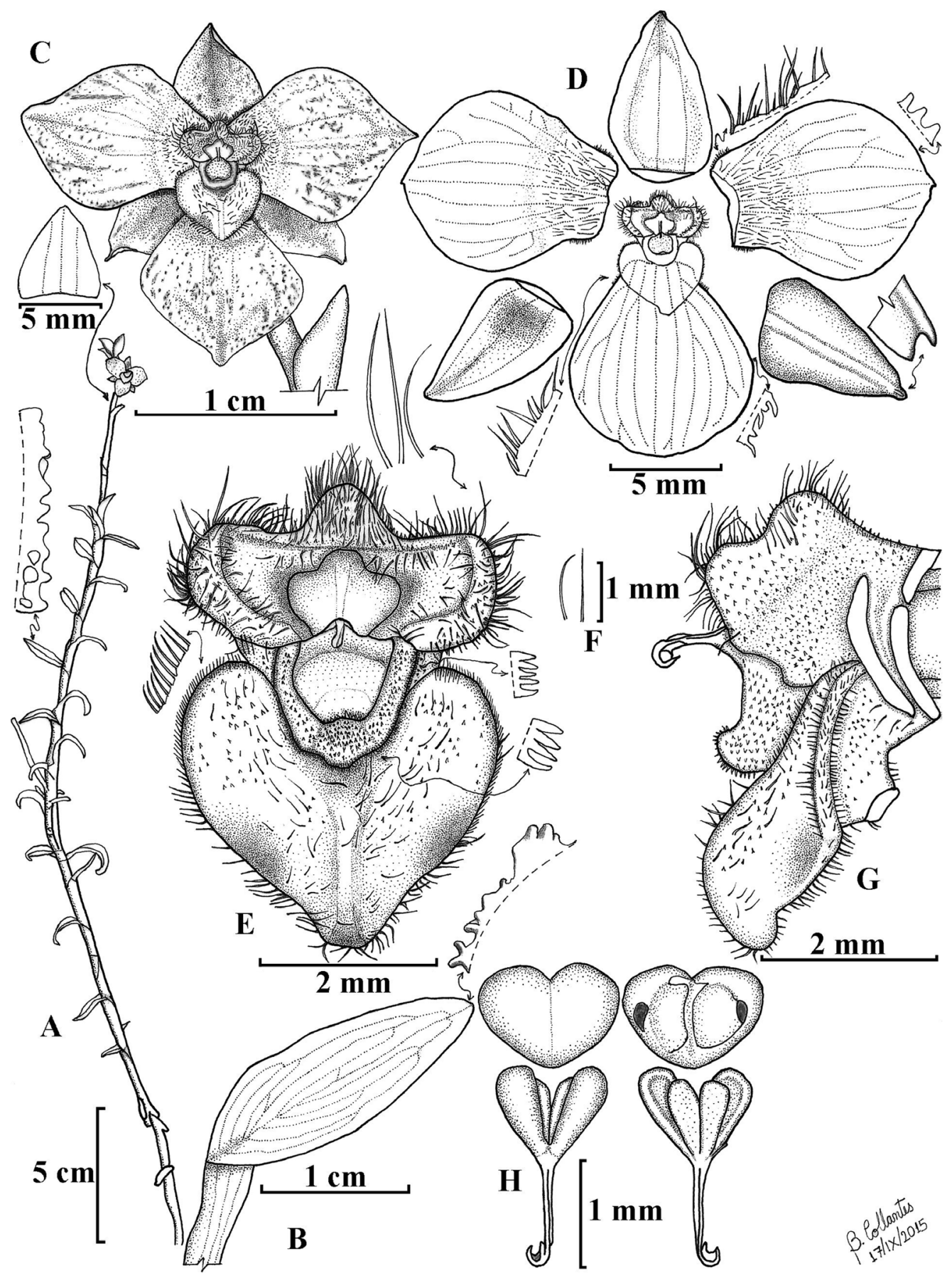

Figure 1. Telipogon phuyupatamarcensis. A. Habit, with details of the leaf and an inflorescence bract. B. Leaf, with margin details. C. Flower, frontal view. D. Dissected flower with expanded perianth and details of the margins. E. Callus and column, frontal view with details of the surface and setae. F. Setae, frontal views. G. Callus and column, lateral view. H. Pollinarium, frontal and ventral view with details of the anther cap, pollinia, caudicle and viscidium. Drawn from $B$. Collantes et al. 354 by B. Collantes. 
Huamán, J. Farfán \& F. Carazas 4999 (holotype: CUZ!).

Terrestrial herb, up to $40 \mathrm{~cm}$ tall (including the inflorescence), erect or procumbent. Roots $3 \mathrm{~mm}$ in diameter, appearing along the basal half of the stem. Stem 26-30 cm long, erect or procumbent, leafy, terete, with branches from the middle to the upper nodes. Leaves 22-28, distichous, subcoriaceous; petiole $10 \times 3 \mathrm{~mm}$, conduplicate, amplexicaul; sheath 8-20 $\times 5-8 \mathrm{~mm}$, ovate to sublanceolate, entire margin, minute and irregularly papillose, apex subacute with minute mammillary papillae. Inflorescence $1-2,5.0-$ $18.5 \mathrm{~cm}$ long, apical, erect or procumbent, racemose, pedunculated, simultaneously in anthesis; peduncle terete. Floral bract ovate-deltate, amplexicaul, basal bigger than apical bracts. Ovary $6 \times 2 \mathrm{~mm}$, terete, pedicelate; pedicel $5 \times 1 \mathrm{~mm}$, terete. Flowers resupinate, successive anthesis, $1.8 \times 1.5 \mathrm{~cm}$. Sepals free, extended, entire margins, greyish ochre with abundant and irregular brownish spots and dots; dorsal sepal ovate, deeply concave, the dorsum slightly keeled, subacute, 3 -veined, $7 \times 4 \mathrm{~mm}$; lateral sepals similar to dorsal sepal, mucronate apex. Petals $9 \times 7.5 \mathrm{~mm}$, free, extended, suborbicular, rounded apex with minuscule apicule, 9-veined, some veins anastomosed, entire margin ornate of conical papillae, toward the bottom minutely setulose, setose ventral and basal surface, greyish ochre with abundant and irregular brownish spots and dots. Labellum $8.5 \times 8.0$ $\mathrm{mm}$, widely ovate, rounded apex, 11-veined, veins anastomosed toward the apex, entire margin with minutely very acute denticle and conical papillae, towards the bottom minutely setulose, greyish ochre with abundant and irregular brownish spots and dots; callus $3.5 \times 3.8 \mathrm{~mm}$, widely cordiform, entire margin, reddish brown covert by greyish white setae, the first half densely setulose-retrorse, second half densely setose, ventral surface setose, longitudinal conspicuous keel in the middle. Column $2.0 \times 3.5 \mathrm{~mm}$, widely auriculate ( 2 , at both sides of the column) with a dome on the superior medial part, reddish brown covert by reddish brown setae, densely setose, erect or incurvate setae, the longer ones with more than $1 \mathrm{~cm}$ long; stigmatic cavity orbicule-subpentagonal. Rostellum entire, prolonged as much as the stipe. Anther cap transversely cordiform, 2-celled. Pollinarium $2.0 \times 1.4$ $\mathrm{mm}$; pollinia 4 , in 2 unequal pairs, the outer pair larger, obovoid, concave-convex the bigger, the inner pair convex-plane; caudicles hyaline; viscidium ancistrous.

Additional material examined: PeRU. Cusco: Prov. Urubamba, Dist. Machu Picchu, Phuyupatamarca, 3650 m, 11 Jul 2011, B. Collantes, E. Machaca \& C. Soto 354 (USM!); same area, 3600 m, 26 Jul 2014, $C$. Martel, B. Collantes \& J. Ochoa 46 (USM!).

Distribution AND habitat: Recorded in the Machu Picchu Historical Sanctuary (Urubamba province). Galiano et al. (2003) pointed out that it is also distributed in the provinces of $\mathrm{La}$ Convención and Paucartambo. However, the individuals from Paucartambo correspond instead to Telipogon tupayachii Nauray \& A. Galán (Nauray \& Galán, 2008). Therefore, Telipogon phuyupatamarcensis is currently known from two localities in Urubamba and La Convención provinces between 3200 and $3700 \mathrm{~m}$, growing in small patches (Fig. 2).

Ecology: Telipogon phuyupatamarcensis grows in foggy environments at high altitudes of the Andes (i.e. subtropical montane forest), which are characterized by presenting small and dispersed shrubby species (e.g. Polylepis). The species is found associated with Sphagnum L. plants. Pods were frequently observed. Flowering occurs during the dry-season, from May to August, with the peak between June and July.

CONSERVATION STATUS: The populations occurring within the Machu Picchu Sanctuary (Phuyupatamarca and Chakicocha) may not be under threat, since we recorded several individuals naturally occurring (Martel, 2014; Collantes, pers. obs.). However, the population of La Convención might be due to livestock. Anthropic activities might imperil its small populations that we calculated in around 250 individuals occupying less than $10 \mathrm{~km} 2$ along its distribution range. According to the IUCN Red List (IUCN, 2014), it can be listed endangered (EN, criterion B2/extent of occurrence and $\mathrm{D} /$ very small or restricted population).

TAXonomic nOtes: The original material of $T$. phuyupatamarcensis consisted of five duplicates (Galiano et al., 2003). However, only the type collection, a sheet presenting two pressed individuals, was found at CUZ. The information provided in the 

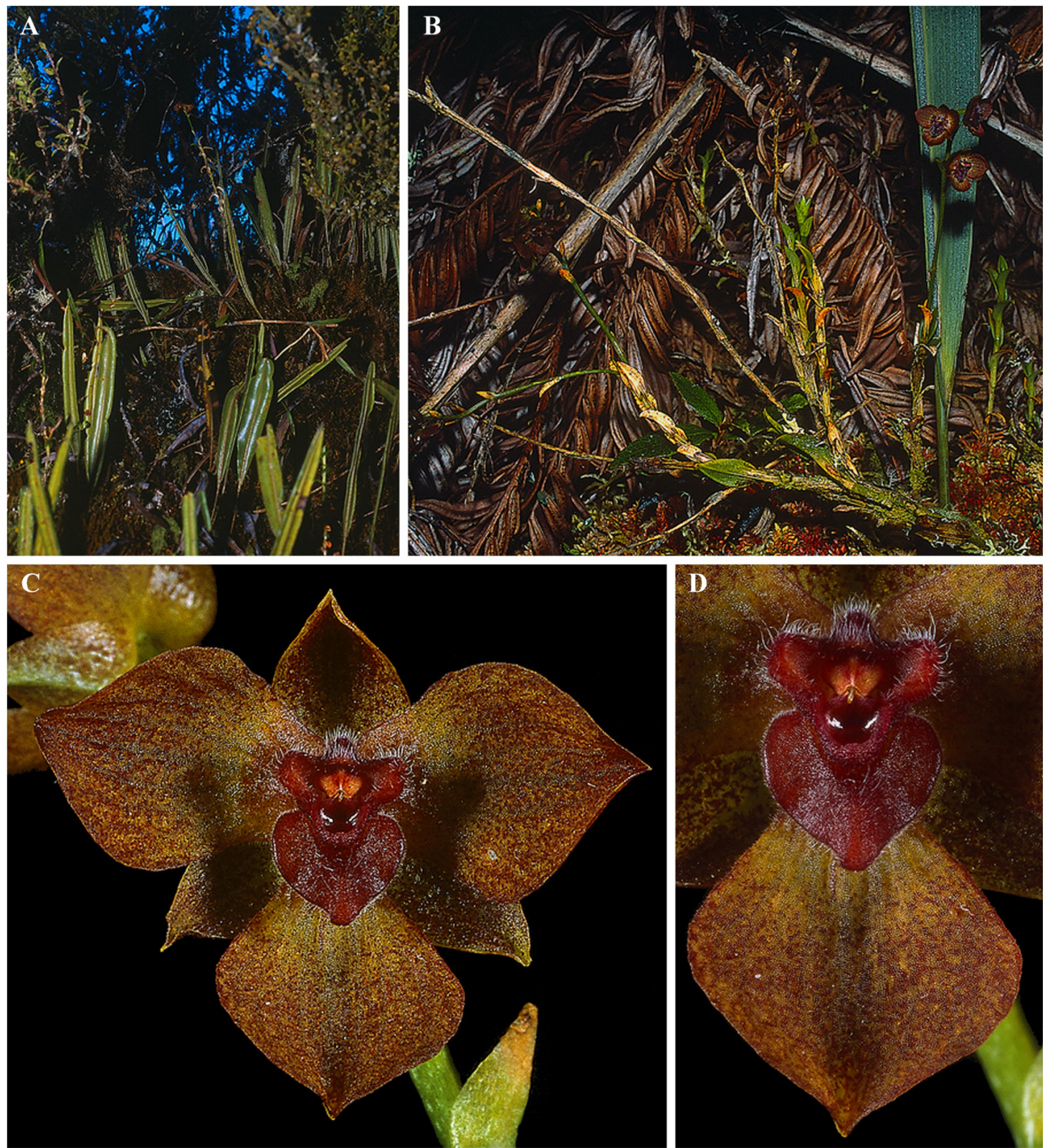

Figure 2. Telipogon phuyupatamarcensis. A. Plant growing associated to Spaghnum. B. Habit, with details of its branched stem. C. Flower, frontal view, with details of the perianth and column. D. Lip and column, frontal view, with detail of the setae on the callus and column. Photographs by B. Collantes.

type voucher was slightly different to that recorded by Galiano et al. (e.g. the date and locality of collection). Although Galiano et al. (2003) pointed out that the leaves are seated, $T$. phuyupatamarcensis presents a conspicuous amplexicaul petiole. The petals and labellum of $T$. phuyupatamarcensis are suborbicular and widely ovate, respectively, not ovate. They have made a mistake when recording the perianth size by using $\mathrm{cm}$ instead of $\mathrm{mm}$ in the species description and diagnosis. Although in the original description of T. phuyupatamarcensis there are no details about the callus morphology, the line drawing presented by 
the authors shows a trilobed callus, even though the structure is widely cordate (Fig. 2).

Two floral characteristics are distinctive in $T$. phuyupatamarcensis: (a) presence of a conspicuous widely cordiform callus; and (b) an auriculate column (Figs. 1-2). Although Galiano et al. (2003) pointed out that the species is related to $T$. benedicti Rchb. f., we consider that it might be closely related to $T$. tupayachii instead due to similarities on the callus and column (auriculate in both) morphology (Nauray \& Galán, 2008). Nauray and Galán (2008) pointed out that $T$. phuyupatamarcensis presents a glabrescent column and unbranched veins; however it is indeed pilose and the veins are branched. Telipogon phuyupatamarcensis and T. tupayachii differ in their callus form (widely cordiform in the former and sagittate-conical in the latter), the setae on the column (longer setae in $T$. tupayachii), and the veins of the petals and lip (brown branched veins with brown spots in the former and purple branched veins in the latter).

ACKNOWLEDGMENTS. José Koechlin (Inkaterra) is thanked for supporting our investigation on Machu Picchu Sanctuary' orchids; Roger Valencia (Auqui Tours), Julio Ochoa (MINCUL) and Eufemia Machaca (UNSAAC) kindly helped during the fieldwork at Machu Picchu. Martín Timaná de la Flor (PUCP) kindly reviewed the manuscript. The Jefatura del Santuario Histórico de Machupicchu of the Servicio Nacional de Áreas Naturales Protegidas (SERNANP) of Peru issued the collection permit under which orchid specimens have been collected $\left(\mathrm{N}^{\circ}\right.$ 009-2010-SERNANP-SHM-J).

\section{LiTERATURE CITED}

Christenson, E. A. (2003). Machu Picchu Orchids: A Manual to the Orchids of the Machu Picchu Historical Sanctuary. Fondo Nacional para Áreas Naturales Protegidas, INRENA, Cusco, Peru.

Collantes, B. \& Martel, C. (2015). Telipogon koechlinorum (Orchidaceae), a new species from Machu Picchu, Peru. Brittonia, 67, 113-117.

Dodson, C. H. (2003). Why are there so many orchid species? Lankesteriana, 7, 99-103.

IUCN. (2014). Guidelines for using the IUCN Red List categories and criteria. Version 11. Prepared by the Standards and Petitions Subcommittee in February 2014. Available from: http://www.iucnredlist.org/ documents/RedListGuidelines.pdf. Accessed 21-102015.

Galiano, W., Núñez, M. P., Tupayachi, A. \& Calatayud, G. (2003). Una nueva especie de Telipogon (Orchidaceae) del sureste peruano. Cantua, 11, 11-14.

Martel, C. (2014). An overview of Telipogon diversity at the Machu Picchu Historical Sanctuary. Orchids, 83, 618-621.

Martel, C. \& Nauray, W. (2013). Notes and an emended description of Telipogon peruvianus (Orchidaceae: Oncidiinae). Candollea, 68, 245-250.

Nauray, W. \& Christenson, E. A. (2003). Telipogons from Peru. Two new species from Machu Picchu and environs. Orchids, 72, 696-698.

Nauray, W. \& Galán, A. (2008). Ten new species of Telipogon (Orchidaceae, Onciidinae) from southern Peru. Anales del Jardín Botánico de Madrid, 65, 73-95.

Pridgeon, A. M., Cribb, P. J., Chase, M. A. \& Rasmussen, F. N. (2009). Genera Orchidacearum, vol. 5: Epidendroideae (part two). Oxford University Press, Oxford.

Roque, J. \& León, B. (2006). Orchidaceae endémicas del Perú. Revista Peruana de Biología, 13, 759s-878s.

Ulloa Ulloa, C., Zarucchi, J. L. \& León, B. (2004). Diez años de adiciones a la flora del Perú: 1993-2003. Arnaldoa (Edic. Esp. Noviembre 2004), 1-242. 
